\title{
Evaluasi Konteks Dalam Program Pemberdayaan Masyarakat PT. Ceria Nugraha Indotama di Kecamatan Wolo Kabupaten Kolaka
}

\author{
Iswadi Amiruddin ${ }^{1 *}$, Hasniati², Muhammad Yunus ${ }^{3}$ \\ ${ }^{1}$ Departemen Administrasi Publik, Universitas Hasanuddin, Indonesia \\ ${ }^{2}$ Departemen Administrasi Publik, Universitas Hasanuddin, Indonesia \\ ${ }^{3}$ Departemen Administrasi Publik, Universitas Hasanuddin, Indonesia
}

\begin{abstract}
The research objective was to see the evaluation of the context in the community empowerment program of PT. Ceria Nugraha Indotama In Wolo District, Kolaka Regency. The method used in this research is a qualitative method. The research was conducted at the PT. Cheers Nugraha Indotama. Research informants are one example of a person. The results showed that the evaluation of the context in the community empowerment program of PT. Ceria Nugraha Indotama In Wolo District, Kolaka Regency on the aspect of the organization of the PT. Ceria Nugraha Indotama has committed both to the government or the surrounding community to carry out the company's obligations, namely the CSR / PPM program to the community, but in the aspect of social mapping / social mapping, the company has indeed fulfilled the needs of the community but has not been maximized because it can be seen from the program that monitors and empowers the community to improve his standard of living so that it needs more appropriate attention and programming. The suggestion in this research is the need for in-depth social mapping from the corporate responsibility team so that the community is able to feel the benefits of the presence of the company.
\end{abstract}

Keywords: evaluation, context, community empowerment program

\begin{abstract}
Abstrak
Tujuan penelitian adalah untuk mengetahui evaluasi konteks dalam program pemberdayaan masyarakat PT. Ceria Nugraha Indotama Di Kecamatan Wolo Kabupaten Kolaka. Metode yang digunakan dalam penelitian adalah metode kualitatif. Penelitian dilakukan di Kantor PT. Ceria Nugraha Indotama. Informan penelitian adalah berjumlah 8 orang. Hasil penelitian menunjukkan bahwa evaluasi konteks dalam program pemberdayaan masyarakat PT. Ceria Nugraha Indotama Di Kecamatan Wolo Kabupaten Kolaka pada aspek orinetasi program PT. Ceria Nugraha Indotama telah berkomitmen baik dengan pemerintah maupun masyarakat sekitar pertambangan untuk menjalankan kewajiban perusahaan yakni program CSR/PPM ke masyarakat, namun pada aspek pemetaan sosial/social mapping memang perusahaan telah melakukan identifikasi kebutuhan masyarkaat namun belum maksimal karena terlihat kurangnya program yang menyentuh dan memberdayakan masyarakat untuk meningkatkan taraf hidupnya sehingga di perlukan perhatian dan program yang lebih tepat. Saran dalam penelitian ini adalah perlunya pemetaan sosial yang mendalam dari tim penanggung jawab dari perusahaan agar masyarakat mampu merasakan manfaat hadirnya perusahaan.
\end{abstract}

Kata Kunci: evaluasi, konteks, program pemberdayaan masyarakat

\footnotetext{
*iswadi445@gmail.com
} 


\section{PENDAHULUAN}

Tanggung jawab sosial adalah komitmen perusahaan yang menekankan bahwa perusahaan harus mengembangkan etika bisnis dan praktik bisnis yang berkesinambungan (sustainable) secara ekonomi, sosial dan lingkungan. Konsep ini berkaitan dengan perlakuan terhadap stakeholder baik yang berada di dalam dan di luar perusahaan dengan bertanggung jawab baik secara etika maupun sosial. Hal terpenting dari pelaksanaan tanggung jawab sosial adalah memperkuat keberlanjutan perusahaan itu sendiri dengan jalan membangun kerjasama antar stakeholder yang difasilitasi perusahaan tersebut dengan menyusun programprogram pengembangan masyarakat di sekitarnya. CSR juga mengandung pengertian bahwa seperti halnya individu, perusahaan memiliki tugas moral untuk berlaku jujur, mematuhi hukum, menjunjung integritas, dan tidak korup. Tanggung jawab sosial perusahaan telah menjadi suatu kebutuhan yang dirasakan bersama antara pemerintah, masyarakat, dan dunia usaha berdasarkan prinsip kemitraan dan kerjasama Suharto (2007) dalam bukunya yang berjudul Corporat Social Responsibility: A Strategic Management.

Beberapa daerah telah berhasil melaksanakan program CSR-nya, salah satunya keberhasilan dapat diamati pada PT. Semen Gresik dalam memberdayakan masyarakat sekitar perusahaan dengan membangun kemitraan sebagai sebuah strategi. Perusahaan ini mampu dan berhasil membangun kemitraan bersama dengan Koalisi Perempuan Ronggolawe untuk peningkatan kapasitas perempuan dalam membatik dan mentransfer pengetahuan tentang motif-motif batik sekaligus mendapatkan bantuan berupa peralatan untuk membatik (Hayati \& Suparjan, 2017). Dari tulisan ini penulis ingin menyampaikan bahwa perusahaan yang hadir ditengah-tengah masyarakat saat ini pada dasarnya mampu untuk melakukan berbagai transformasi sosial masyarakat menuju kondisi yang diharapkan yaitu kesejahteraan (Baihaqi, 2015).

Sedangkan secara internal pelaksanaan program tersebut adalah membangun hubungan yang harmonis dan kondusif dengan pemangku kepentingan (stakeholder) yang ada, guna turut berkontribusi dalam pencapaian tujuan korporasi terutama dalam membangun reputasi. Visi pelaksanaan program "Menuju Kehidupan Lebih Baik", dengan kriteria pelaksanaan meliputi lima kriteria pelaksanaan, mencakup kepentingan bersama antara pemerintah, komunitas dan perusahaan, serta memenuhi asas manfaat, berkelanjutan pada wilayah di dekat 
wilayah operasi, publikasi dan mendukung PROPER. Main issue atau dalam pelaksanaan program adalah pelibatan dan pengembangan masyarakat, yang kemudian difokuskan pada empat pilar utama, yaitu Pemberdayaan Ekonomi Masyarakat, Program Kesehatan, Pendidikan, dan Ecopreneurship. Isu utama tersebut dikembangkan berdasarkan karakteristik wilayah kerja di masingmasing wilayah.

Upaya PT. Ceria Nugraha Indotama untuk menunaikan kewajibannya dalam bentuk tanggung jawab sosial awalnya melalui pemberian uang tunai yamg disebut (BST) kompensasi 1 KK mendapatkan 600 ribu perbulan berjalan selama satu tahun kemudian seiring berjalanya waktu perusahan mengevaluasi dan menemukan tidak memberi dampak positif yang siknifikan ditambah hadirnya regulasi kementerian energi sumber daya mineral yang mengharuskan semua perusahan yang bergerak dibidang pengusahaan mineral atau batubara yang meliputi tahapan kegiatan penyediaan umum, eksplorasi, studi kelayakan, konstruksi, penambangan, pengolahan dan pemurnian, pengangankutan dan penjualan, serta pascatambang wajib melakukan tanggung jawab sosialnya melalui pengembangan dan pemberdayaan sehingga tepat pada tahun 2017 PT. Ceria Nugraha Indotama merubah konsep lewat pembangunan dan pemberdayan masyarakat sekitar tambang yang sifatnya berkelanjutan dengan mengacu pada 6 bidang sesau dengan regulasi kementrian yaitu: bidang pendidikan, kesehatan, kemandirian ekonomi, sosial budaya, lingkungan dan, infrastruktur dengan tujuan untuk memberdayakan masyarakat yang dilakukan melalui usaha-usaha yang terorganisir untuk memperbaiki kondisi kehidupan masyarakat, serta meningkatkan kemampuan masyarakat melalui integritas dan kemandirian sehingga lebih bernuansa pembangunan berkelanjutan.

Evaluasi program adalah suatu rangkaian kegiatan yang dilakukan dengan sengaja untuk melihat tingkat keberhasilan program. Ada beberapa pengertian tentang program sendiri. Dalam kamus (a) program adalah rencana, (b) program adalah kegiatan yang dilakukan dengan seksama. Melakukan evaluasi program adalah kegiatan yang dimaksudkan untuk mengetahui seberapa tinggi tingkat keberhasilan dari kegiatan yang direncanakan (Suharsimi, 1993).

Menurut Endang Mulyatiningsih (2011), evaluasi program dilakukan dengan tujuan untuk : (1) Menunjukkan sumbangan program terhadap pencapaian tujuan organisasi. Hasil evaluasi ini penting untuk mengembangkan program yang sama ditempat lain, (2) mengambil keputusan tentang keberlanjutan sebuah 
program, apakah program perlu diteruskan, diperbaiki atau dihentikan.

Wirawan (2012) menyatakan bahwa pendekatan yang berorientasi pada pemegang keputusan (a decision oriented evaluastion approach structured) untuk menolong administrator dalam membuat keputusan, dimana evaluasi sebagai suatu proses yang menggambarkan, memperoleh dan menyediakan informasi yang berguna untuk menilai alternatif keputusan dan membuat pedoman kerja untuk melayani para manajer dan administrator dengan membagi evaluasi menjadi empat macam yaitu salah satunya evaluasi konteks (context evaluation) yang dimana konteks evaluasi ini membantu merencanakan keputusan, menentukan kebutuhan yang akan dicapai oleh program dan merumuskan tujuan program. Stufflebeam (2002) menyebutkan tujuan evaluasi konteks yang utama dalah untuk mengetahui kekuatan dan kelemahan yang dimiliki evaluan. Dengan mengetahui kekuatan dan kelemahan ini, evaluator akan dapat memberikan arah perbaikan yang diperlukan. Menurut Arikanto Suharsimi (2009) bahwa evaluasi konteks adalah upaya untuk menggambarkan dan merinci lingkungan kebutuhan yang tidak terpenuhi, populasi dan sampel yang dilayani, tujuan proyek.

Evaluasi konteks dimulai dengan melakukan analisis konseptual dalam mengidentifikasikan dan merumuskan domain yang akan dinilai, kemudian diikuti dengan analisis empiris tentang aspek yang dinilai, melalui survei, tes. Pada bagian berikutnya, melibatkan kedua cara tersebut (analisis konseptual dan analisis empiris) dalam rangka menemukan masalah utama dalam aspek yang dinilai.

Pengertian evaluasi (evaluation) kerap dibaurkan dengan konsep sejenis lain seperti monitoring atau appraisal. Dalam prakteknya, keseluruhan konsep tersebut memang saling berkait-erat, namun akan berbeda jika dikaitkan dengan substansi yang hendak diukur. Secara konseptual evaluasi merupakan upaya menilai keseluruhan sejumlah hasil dari sebuah kegiatan atau program pembangunan. Konsep monitoring akan lebih spesifik memfokuskan penilaian pada hal tertentu saja seperti keadaan antar waktu saat program masih dalam proses implementasi. Jika didefinisikan, evaluasi merupakan upaya bagaimana menilai capaian tertentu sebuah program atau kegiatan pembangunan "assessing the value". Menilai hasil atau capaian kegiatan bisa berupa kegiatan proyek atau program, baik di pertengahan maupun di akhir program. Tujuan utama melakukan evaluasi adalah untuk memastikan bahwa program yang dilakukan berjalan sebagaimana rencana yang dibuat serta sesuai dengan tujuan akhir yang hendak 
dicapai. Karenanya, variabel utama yang perlu dinilai dalam evaluasi mengacu kepada variabel tujuan program atau proyek dan kemudian mengukurnya seberapa jauh capaian program menurut indikator tujuan dimaksud. Monitoring merupakan penilaian saat tertentu saja atas program atau proyek yang masih sedang berjalan.

Bentuk evaluasi berkaitan dengan konsep evaluasi, dapat dibedakan tiga bentuk evaluasi, yakni formative evaluation, summative evaluation, dan empowerment evaluation merupakan penilaian untuk meningkatkan kinerja atau kinerja program, biasanya dilakukan saat program masih atau sedang berjalan. Evaluasi seperti ini banyak dilakukan di pertengahan program, dimaksudkan untuk memastikan bahwa program berjalan sesuai rencana dan jadwal sehingga tujuan dapat tercapai tepat waktu. Evaluasi sumatif (summative evaluation) adalah evaluasi di akhir program untuk memastikan bahwa program yang dijalankan berhasil atau gagal menurut tujuan program. Penilaian seperti ini diperlukan untuk memastikan bahwa jika program yang sama diterapkan di tempat lain yang konteksnya relatif sama maka akan diperoleh tingkat keberhasilan yang sama pula. Oleh sebab itu, dalam evaluasi sumatif, penilaian dilakukan secara menyeluruh terhadap elemen perencanaan dan variabel tujuan yang hendak dicapai. Bentuk ketiga, yakni evaluasi pemberdayaan (empowerment evaluation), adalah penilaian untuk melihat tingkat keberhasilan kegiatan atau program menurut ukuran "pemberdayaan," seperti capacity building, kemampuan mengelola organisasi, peningkatan kesadaran pemanfaat serta aspek lain terkait dengan konsep pemberdayaan. Dengan tujuan program seperti ini, maka penilaian hasil program berbeda dengan bentuk evaluasi lainnya, yakni menilai seberapa besar "tingkat kemandirian" penerima jika program sepenuhnya dilaksanakan mereka.

Menurut Zaenal (2016) mengatakan bahwa evaluasi adalah suatu proses bukan suatu hasil (produk). Hasil yang diperoleh dari kegiatan evaluasi adalah kualitas sesuatu, baik yang menyangkut tentang nilai atau arti, sedangkan kegiatan untuk sampai pada pemberian nilai dan arti itu adalah evaluasi.

Menurut Isbandi Rukminto (2000) mengatakan bahwa pemberdayaan masyarakatb community emprowment pada intinya adalah membantu klien pihak yang diberdayakan untuk memperoleh daya guna menagambil keputusan dan menentukan tindakan yang akan ia lakukan tentang diri mereka, termasuk mengurangi efek hambatan pribadi dan sosial melalui peningkatan kemampuan dan rasa percaya diri untuk menggunakan daya yang 
dimiliki antara lain melalui transfer daya lingkungan.

Menurut Sumaryadi

pemberdayaan masyarakat adalah upaya mempersiapkan masyarakat seiring dengan langkah memperkuat kelembagaan masyarakat agar mereka mampu mewujudkan kemajuan, kemandirian, dan kesejahteraan dalam suasana keadilan sosial yang berkelanjutan.

Abu Huraerah (2008) mengatakan bahwa pemberdayaan masyarakat adalah sebuah proses dalam bingkai usaha memperkuat apa yang lazim disebut community self-reliance atau kemandirian. Dalam proses ini masyarakat didampingi untuk membuat analisis masalah yang dihadapi, dibantu untuk menemukan alternatif solusi masalah tersebut, serta diperlihatkan strategi memanfaatkan berbagai kemampuan yang dimiliki.

Menurut Widjaja

(2002) pemberdayaan masyarakat adalah upaya meningkatkan kemampuan dan potensi yang dimiliki masyarakat sehingga masyarakat dapat mewujudkan jati diri harkat 18 dan martabatnya secara maksimal untuk bertahan dan mengembangkan diri secara mandiri baik di bidang ekonomi, sosial, agama dan budaya.

Menurut Abu Huraerah (2008) mengatakan bahwa pemberdayaan masyarakat adalah sebuah proses dalam bingkai usaha memperkuat apa yang lazim disebut community self-reliance atau kemandirian. Dalam proses ini masyarakat didampingi untuk membuat analisis masalah yang dihadapi, dibantu untuk menemukan alternatif solusi masalah tersebut, serta diperlihatkan strategi memanfaatkan berbagai kemampuan yang dimiliki.

\section{METODE PENELITIAN}

Penelitian ini menggunakan jenis penelitian deskriptif kualitatif yaitu suatu penelitian dimana peneliti berusaha mendeskripsikan atau menggambarkan tentang evaluasi konteks dalam program pemberdayaan masyarakat PT. Ceria Nugraha Indotama Di Kecamatan Wolo Kabupaten Kolaka.

Peneliti dalam melakukan pengumpulan data primer yakni berupa (1) observasi merupakan instrumen pengumpulan data yaitu dengan melakukan pengamatan langsung terhadap objek yang diteliti dan dimaksudkan untuk mendapatkan data primer dan sekunder yang relevan dengan permasalahan peneliian mengenai efektivitas program Corporate Social Responsibility (CSR) PT. Ceria Nugraha Indotama dalam pemberdayaan masyarakat di Kecamatan Wolo Kabupaten Kolaka, (2) observasi merupakan instrumen pengumpulan data yaitu dengan melakukan pengamatan 
langsung terhadap objek yang diteliti dan dimaksudkan untuk mendapatkan data primer dan sekunder yang relevan dengan permasalahan peneliian mengenai efektivitas program Corporate Social Responsibility (CSR) PT. Ceria Nugraha Indotama dalam pemberdayaan masyarakat di Kecamatan Wolo Kabupaten Kolaka, (3) dokumentasi yaitu mengumpulkan data dengan cara mengambil data-data dari catatan, dokumentasi, administrasi yang sesuai dengan masalah yang diteliti. Dalam hal ini dokumentasi diperoleh merupakan hal yang penting dalam membuktikan validitas sebuah data ataupun hasil penelitian maka dianggap perlu oleh peneliti mengambil dokumentasi pada setiap kegiatan penelitian yang dilakukan, dokumentasi yang akan diambil yaitu berbentuk rekaman atau foto yang berkaitan dengan efektivitas program Corporate Social Responsibility (CSR) PT. Ceria Nugraha Indotama dalam pemberdayaan masyarakat di Kecamatan Wolo Kabupaten Kolaka.

\section{HASIL DAN PEMBAHASAN}

Upaya pemberdayaan masyarakat haruslah pertama-tama dimulai dari pemihakan dan pemberian kesempatan kepada masyarakat yang lemah dengan menciptakan suasana atau iklim yang memungkinkan potensi individu dalam masyarakat dapat berkembang. Dalam hal ini titik tolaknya adalah pengenalan dan penyadaran kepada masyarakat bahwa setiap manusia memiliki potensi yang dapat berkembang. Artinya, bahwa tidak seorang individu pun yang tidak mempunyai daya sama sekali. Salah satu pendekatan dalam pemberdayaan masyarakat agar dapat berlangsung dan mencapai keberhasilan dilakukan melalui pemberian bimbingan dan dukungan oleh pemangku kepentingan pembangunan yang berpihak kepada masyarakat agar masyarakat mampu menjalankan peranan dan tugas-tugas kehidupan masyarakat (Suharto, 2007).

Upaya pemihakan kepada kelompok masyarakat yang lemah perlu dilakukan dalam bidang-bidang kebutuhan dasar manusia; kebutuhan ekonomi, dan kebutuhan politik. Apabila tidak ada keberpihakan dari pemerintah atau sumber-sumber kekuasaan kepada masyarakat lemah akan menimbulkan gejolak protes dari masyarakat yang secara ekstrim dapat berupa revolusi. Pemberdayaan masyarakat dalam menciptakan suasana kondusif dapat dilakukan melalui pemberian dukungan dari pemangku kepentingan pembangunan yang berpihak kepada masyarakat. Dukungan utama diberikan oleh pihak pemerintah dalam bentuk kebijakan pengarusutamaan pembangunan daerah 
melalui pendekatan pemberdayaan masyarakat.

Konteks evaluasi ini membantu merencanakan keputusan, menentukan kebutuhan yang akan dicapai oleh program dan merumuskan tujuan program. Stufflebeam (2002) menyebutkan, tujuan evaluasi konteks yang utama dalah untuk mengetahui kekuatan dan kelemahan yang dimiliki evaluan. Dengan mengetahui kekuatan dan kelemahan ini, evaluator akan dapat memberikan arah perbaikan yang diperlukan. Menurut Arikanto Suharsimi (2009) menjelaskan bahwa evaluasi konteks adalah upaya untuk menggambarkan dan merinci lingkungan kebutuhan yang tidak terpenuhi, populasi dan sampel yang dilayani, tujuan proyek.

Konteks evaluasi ini membantu merencanakan keputusan, menentukan kebutuhan yang akan dicapai oleh program dan merumuskan tujuan program. Sesuai dengan konsep atau teori yang di gunakan bahwa efektivitas program pemberdayaan masyarakat dapat dilihat dari evaluasi konteks yang diukur dengan berdasarkan beberapa indikator.

Untuk dapat melihat evaluasi konteks dalam program pemberdayaan masyarakat PT. Ceria Nugraha Indotama Di Kecamatan Wolo Kabupaten Kolaka penulis menggunakan indikator konteks yang memiliki sub indikator yakni orientasi program serta pemetaan sosial/social mapping.

\section{Orientasi Program}

Pada dasarnya masi banyak perusahaan tidak mau menjalankan program-program CSR karewna melihat hal tersebut hanya sebagai pengeluaran biaya (cos center). CSR memang tidak memberikan hasil secara keungan dalam jangka pendek. Namun CSR akan memberikan hasil baik langsung maupun tidak langsung pada keungan perusahan di masa mendatang. Dengan demikian apabila perusahaan melakukan programprogram CSR diharapkan keberlanjutan perusahaan akan terjamin dengan baik. Oleh karena itu, program- program CSR lebih tepat apabila digolongkan sebagai investasi dan harus menjadi strategi bisnis dari suatu perusahaan. Lesmana (2006) sehingga pada akhirnya keberlanjutan yang diharapkan akan dapat terimplementasikan berdasarkan harapan semua stakeholder (Asri \& Insari, 2020).

Program Pengembangan dan Pemberdayaan Masyarakat (PPM) adalah upaya yang dilakukan dalam rangka mendorong peningkatan perekonomian, pendidikan, sosial budaya, kesehatan dan lingkungan kehidupan masyarakat sekitar tambang, baik secara individual maupun kolektif agar tingkat kehidupan masyarakat sekitar tambang menjadi lebih baik dan 
mandiri. Mengacu kepada Rencana Induk Pengembangan dan Pemberdayaan Masyarakat (RI PPM) tahun 2017 - 2021 PT Ceria Nugraha Indotama, yang merupakan hasil sosial mapping yang telah dilaksanakan pada bulan februari 2017, program pengembangan dan pemberdayaan masyarakat PT Ceria Nugaraha Indotama terbagi dalam 6 pilar program prioritas yaitu bidang pendidikan, kesehatan, kemandirian ekonomi, sosial budaya, lingkungan serta infrastruktur.

Program pengembangan dan pemberdayaan masyarakat (PPM) adalah upaya yang dilakukan dalam rangka mendorong peningkatan perekonomian, pendidikan, sosial budaya, kesehatan dan lingkungan kehidupan masyarakat sekitar tambang, baik secara individual maupun kolektif agar tingkat kehidupan masyarakat sekitar tambang menjadi lebih baik dan mandiri. Mengacu kepada rencana induk pengembangan dan pemberdayaan masyarakat (RI PPM) tahun 2018 - 2021 PT Ceria Nugraha Indotama, yang merupakan hasil sosial mapping yang telah dilaksanakan pada bulan februari 2018 dan 2019, program pengembangan dan pemberdayaan masyarakat PT Ceria Nugaraha Indotama terbagi dalam 6 pilar program prioritas yaitu bidang pendidikan, kesehatan, kemandirian ekonomi, sosial budaya, lingkungan serta infrastruktur yang memiliki tujuan untuk memperbaiki citra perusahaan di mata masyarakat, menjalankan aturan menteri energi sumber daya mineral yang mengharuskan perusahaan menjalankan tanggung jawabnya, serta terlebih lagi mensejahterakan masyarakat sekitar pertambangan. Serta pada pemetaan sosial/ social mapping yang dimana tahap perencanaan program, proses pemberdayaan dilakukan dengan cara melibatkan masyarakat untuk berpikir tentang jenis kegiatan apa yang akan dilaksanakan. Dimana masyarakat dilibatkan dalam proses perencanaan. Dari sudut proses, pengelolaan mencakup unsur-unsur dalam manajemen, baik secara lengkap maupun secara sederhana. Sehingga pelaksanaan pemetaan sosial untuk menggali dan mengetahui kebutuhan-kebutuhan masyarakat sekitar pertambangan sehingga program pemberdayaan masyaraakt yang lahir nantinya atas dasar kebutuhanya.

Berdasarkan pada informan mengenai orientasi program dalam program pemberdayaan masyarakat CSR/PPM PT. Ceria Nugraha Indotama dapat disimpulkan bahwa awal tahun 2013 perusahaan PT. Ceria Nugraha telah masuk di daerah Kecamatan Wolo untuk melakukan pengelolaan pertambangan dan tepat akhir pada tahun 2017 banyaknya gejolak dan demonstrasi yang dilakukan oleh masyarakat menuntut perusahaan 
untuk memberi tanggung jawab sosialnya ke masyarakat yang terdampak sehingga pasca adanya desakan dari masyarakat barulah perusahaan melakukan tanggung jawab sosial yang berbentuk pemberian langsung uang tunai setiap $\mathrm{KK}$ yang terdampak kemudian diputuskan daerah yang menjadi terdampak yakni 2 kelurahan yaitu Kelurahan Wolo, Kelurahan Ulu Wolo. Kemudian 4 Desa yakni desa saya sendiri yaitu Ponre, Desa Samaenre, Desa Ulu Lapao-Pao, Desa Muara Lapao-Pao. Sertamengenai orientasi program dalam program pemberdayaan masyarakat CSR/PPM PT. Ceria Nugraha Indotama dapat disimpulkan bahwa perusahaan hanya melakukan tanggung jawab sosial yang bentuknya memberi langsung uang tunai ke masyarakat yang terdampak dan pemberian donasi dan bantuan yang memasukkan proposal itu sekitar tahun 2014 kemudian tepat pada tahun 2016 perusahaan telah merubah konsep pelaksanaan tanggung jawab sosial yang dilakukan ke masyarakat yakni membuat program yang berkesinambungan atas dasar kebutuhan masyarakat, meskipun itu belum bisa kita cover semuaya keinginan masyarakat karena masi terkadang mengalami keterbatasan anggaran.

Berdasarkan hasil penelitian yang dilakukan menunjukkan bahwa efektivitas pada evaluasi konteks mengenai orientasi program bahwa perusahaan PT. Ceria
Nugraha Indotama telah berkomitmen baik dengan pemerintah provinsi, pemerintah kabupaten, pemerintah kecamatan dan desa lurah serta yang menjadi terpenting yakni dengan masyarakat untuk menjalankan kewajiban perusahan yang bertujuan agar perusahaan terus menerus menjalankan pengoperasian pengelolaan pertambangan tampah gangguan dan riakan masyarakat dan perusahaan harus menjalankan tanggung jawabnya ke masyarakat baik berbentuk bantuan fisik atau donasi ataupun berbentuk program pemberdayaan masyarakat yang berkelanjutan, ditambah perusahaan terus menjaga citra di masyarakat sekitar pertambangan.

\section{Pemetaan Sosial/Social Mapping}

Hal ini disebabkan mayoritas latar belakang pekerjaan masyarakatnya adalah pekerja ataupun buruh lepas perusahaan tambang. Untuk mengatasi hal tersebut, langkah pertama yang dilakukan PT Pertamina EP Field Sanga-Sanga mulai menyusun tahapan pelaksanaan dan implementasi dari Program CSR Hati Kertajaya. Mengacu pada dokumendokumen program CSR seperti MDGs dan ISO 26000, serta empat pilar utama pelaksanaan CSR/TJSL sebagai main issue, maka dilakukan pertemuan secara langsung antara pihak korporasi dan masyarakat. Pertemuan bertujuan untuk diskusi mendalam guna mengetahui 
kebutuhan awal dari masyarakat Desa Sarij aya, dengan diwakili oleh pengurus dan anggota Karang Taruna. Setelah diketahui pasti permasalahan dan kendala yang dihadapi di lapangan, dilakukan perumusan visi dan misi program, serta target dan strategi pelaksanaan program termasuk didalamnya penyesuaian visi dan misi perusahaan, kebijakan pimpinan, rancangan program, ketersediaan SDM, pemetaan wilayah, alokasi dana, serta strategi implementasi dan evaluasi (Pranoto \& Yusuf, 2016).

Tahap perencanaan program, proses pemberdayaan dilakukan dengan cara melibatkan mereka untuk berpikir tentang jenis kegiatan apa yang akan dilaksanakan. Dimana masyarakat dilibatkan dalam proses perencanaan. Perencanaan merupakan salah satu fungsi dari manajemen atau pengelolaan termasuk pengelolaan komunikasi, baik ditinjau dari segi proses, bentuk maupun komponenkomponen atau unsur-unsur. Dari sudut proses, pengelolaan mencakup unsur-unsur dalam manajemen, baik secara lengkap maupun secara sederhana. Sehingga pelaksanaan pemetaan sosial bertujuang untuk menggali dan mengetahui kebutuhan-kebutuhan masyarakat sekitar pertambangan sehingga program pemberdayaan masyaraakt yang lahir nantinya atas dasar kebutuhanya.
Tanggung jawab sosial perusahaan adalah tanggung jawab yang melekat pada setiap perusahaan penanaman modal untuk tetap menciptakan hubungan yang serasi, seimbang, dan sesuai dengan lingkungan, nilai, norma, dan budaya masyarakat setempat.

Sebelum melakukan implementasi tanggung jawab sosial perusahaan dan perencanaan pengembangan masyarakat, maka diawali melalui pemetaan sosial (Social Mapping). Pemetaan sosial merupakan kegiatan yang dilaksanakan untuk memahami kondisi sosial masyarakat lokal. Kegiatan ini penting untuk dilakukan oleh perusahaan karena setiap masyarakat memiliki kondisi sosial berbeda yang akan menyebabkan masyarakat memiliki masalah dan kebutuhan yang berbeda pula. Pemetaan sosial selain untuk mengetahui kebutuhan dasar masyarakat, potensi sumber daya dan modal sosial masyarakat, juga dilakukan untuk mengenal stakeholder dalam kaitannya dengan keberadaan dan aktivitas pelaku dalam program, mengidentifikasi akar permasalahan yang dirasakan komuniti.

Kemudian mengenai pemetaan sosial/ social mapping bahwa mayoritas perusahaan menjalankan corporate social rensponsibility $\quad(C S R) \quad$ program pemberdayaan masyarakat dengan alakadarnya, program dibuat hanya 
berdasarkan hasil internal assessment, bersifat parsial, instant, proposal base bahkan terkesan trial and error. Sehingga selain tidak efisien model pelaksanaan CSR seperti ini, tidak akan berdampak signifikan terhadap upaya pengembangan dan pemberdayaan masyarakat lokal yang ada disekitar perusahaan. Namun berdasarkan penelitian terlihat bahwa PT. Ceria Nugraha Indotama sebelum menentukan program CSR/PPM yang ingin dijalankan ke masyarakat terlebih dahulu melakukan social mapping atau pemetaan sosial di 2 Kelurahan dan 4 Desa bersama masyarakat selaku target, Pemerintah Desa, Pemerintah Kecamatan, dan pemangku kepentingan lainnya. Keterlibatan masyarakat dan seluruh stakeholders bertujuan menggali apa yang menjadi kebutuhan masyarakat serta agar relevan dan dapat dilaksanakan di tingkat lapangan sekaligus untuk memastikan bahwa targettarget program dapat dicapai dengan baik yang brtujuan untuk menemukan program yang sesuai dengan kebutuhan masyarakat. Meskipun dalam pelaksanaan pemetaan sosial di masyarakat terkadang masih belum berjalan efektif dan penerapanya belum maksimal dalam menggali apa yang menjadi kebutuhan-kebutuhan masyarakat akan tetapi PT. Ceria Nugraha Indotama akan terus berusaha melakukan program pemberdayaan masyarakat atas dasar kebutuhan.

Penjelasan menunjukkan bahwa mengenai pemetaan sosail yang dilakukan oleh perusahaan PT. Ceria Nugraha Indotama dalam hal ini tim CSR/PPM yakni tahap persiapan dalam penentuan program pemberdayaan masyarakat CSR/PPM PT. Ceria Nugraha Indotama diawali dengan sosialisasi, pembentukan kelompok dan pembentukan tim di 2 Kelurahan dan 4 Desa Kecamatan Wolo yang menjadi wilayah ring 1 . Sosialisasi dilakukan melalui pembentukan kelompok bagi masyarakat dan di identifikasi kelompok pekerja dan pembentukan tim di tingkat Desa, sehingga pemberdayaan masyarakat melalui CSR/PPM dilakukan melalui tahap persiapan antara lain yaitu pemetaan sosial, pemetaan pemangku kepentingan dan pemetaan kebutuhan masyarakat setiap tahun. Didasarkan dengan pada kondisi objektif kebutuhan proporsinya masing-masing pada tahap persiapan ini dirumuskan oleh Tim CSR/PPM PT. Ceria Nugraha Indotama dan dikoordinasikan dengan pemangku kepentingan dan target group serta sosialisasi program program pemberdayaan masyarakat yang akan dilaksanakan, sehingga menjadi kewajiban bagi perusahan untuk melakukan pemetaan sosial agar mampu menyerap kebutuhan masyarakat sekitar. 
Kemudian yang menjadi rumusan program pemberdayaan masyarakat merupakan refleksi kondisi rill dan keinginan masyarakat setempat dari hasil pemetaan sosial bersama pemerintah setempat dan masyarakat, yang dalam pelaksanaanya memerlukan peran serta perusahaan secara akhtif sehingga program pengembangan masyarakat sebagai salah satu bentuk tanggung jawab sosial perusahaan dan merupakan investasi program. Meskipun kan berbeda-beda kebutuhan masyrakat setiap desa maupun lurah jadi kami dari Tim CSR/PPM menentukan berdasarkan yang menjadi kebutuhan mendesak masyarakat sehingga yang disepakati itu kebanyakan yang bergerak pada bidang pendidikan, infrastruktur, kesehatan dan lingkungan, meskipun bidang pengembangan ekonomi, sosial budaya tetap kami jalankan.

\section{KESIMPULAN}

Berdasarkan hasil penelitian yang telah dilakukan mengenai evaluasi konteks dalam program pemberdayaan masyarakat PT. Ceria Nugraha Indotama di Kecamatan Wolo Kabupaten Kolaka bahwa pada aspek konteks pada (1) orientasi program dan pemetaan sosial/social mapping PT. Ceria Nugraha Indotama telah berkomitmen untuk melaksanakan tanggung jawab sosial dalam bentuk program pemberdayaan masyarakat yang berkelanjutan yakni pihak perusahaan melakukan program pemberdayaan masyarakat sebagai tanggung jawab sosial dan menajag brand image dimata pemerintah dan masyarakat sekitar pertambangan, (2) serta sebelum menentukan program pemberdayaan masyarakat dalam hal ini Tim CSR/PPM melaksanakan pemetaan sosial bersama pemerintah di 2 kelurahan dan 4 desa serta masyarakat guna menggali atau menemukan kebutuhan-kebutuhan masyarakat di Kecamatan Wolo, dalam proses pemetaan sosial pihak perusahaan melakukan pertemuan bersama pemerintah dan masyarakat guna mendaptkan dan menggali kebutuhan-kebutuhan yang di inginkan masyarakat agar program yang lahir mengalami singkronisasi dan terus berkelanjutan yang akan memberi manfaat kepada masyarakat.(Stufflebeam, 2002).

\section{DAFTAR PUSTAKA}

Abu Huraerah. (2008). Pengorganisasian dan Pengembangan Masyarakat: Model dan. Strategi Berbasis Kerakyatan. UNPAS.

Arikanto Suharsimi. (2009). Dasar-dasar evaluasi pendidikan bumi aksara.

Asri, T. M., \& Insari, F. F. (2020). Evaluasi Program Corporate Social Responsibility (Csr) Program Bank Sampah Delima Pada Pt Pertamina Ep Asset 4 Field Cepu. Profetik: Jurnal Komunikasi, 12(2), 309. https://doi.org/10.14421/pjk.v12i2.17 09 
Baihaqi. (2015.). EVALUASI PROGRAM CSR PT . SOCFINDO TERHADAP. 16-33.

Endang Mulyatiningsih. (2011). Metode Penelitian Terapan Bidang Pendidikan. Alfabeta Pribadi.

Isbandi Rukminto. (2000). Psikologi Sosial dan Ilmu Kesejahteraan Sosial, Dasar-. Dasar Pemikiran. : PT Raja Grafindo.

Pranoto, A. R., \& Yusuf, D. (2016). Program CSR Berbasis Pemberdayaan Masyarakat Menuju Kemandirian Ekonomi Pasca Tambang di Desa Sarij aya. Jurnal Ilmu Sosial Dan Ilmu Politik, 18(1), 39. https://doi.org/10.22146/jsp.13094

Stufflebeam, D. L. (2002). The CIPP Model For Evaluation, dalam Daniel L. Stufflebeam, dkk. (eds), Evaluation in Education and Human Service. Kluwer Academic Publisher.

Suharsimi, A. (1993). Manjemen Penelitian. PT. Raja Grafindo. Persada.

Suharto. (2007). Corporat Social Responsibility: A Strategic Management. Salemba Empat.

Sumaryadi. (2005). Perencanaan Pembangunan Daerah Otonom dan Pemberdayaan Masyarakat. Penerbit Gaya Media.

Widjaja. (2002). Komunikasi dan Hubungan Masyarakat. PT. Bumi Aksara.

Wirawan. (2012). Evaluasi; Teori, Model, Standar, Aplikasi, dan Profesi. Rajawali Press.

Zaenal, A. (2016). Evaluasi Pembelajaran (Prinsip, Teknik, dan Prosedur),. Cetakan Kedelapan. Rosda Karya. 